\title{
The effects of immersion in water on labor, birth and newborn and comparison with epidural analgesia and conventional vaginal delivery
}

\author{
Suda doğumun, travay, doğum ve yenidoğan üzerine etkileri ve epidural analjezi ile \\ normal doğum ve konvansiyonel vajinal doğum ile karşılaştırılması
}

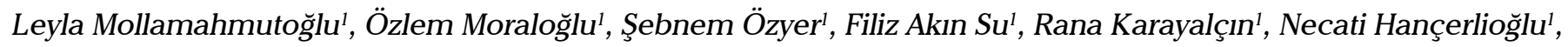
Özlem Uzunlar ${ }^{1}$, Uğur Dilmen²

${ }^{\prime}$ Water Birth Unit, Zekai Tahir Burak Women's Health Education and Research Hospital, Ankara, Turkey

${ }^{2}$ Neonatology Unit, Zekai Tahir Burak Women's Health Education and Research Hospital, Ankara, Turkey

\section{Abstract}

Objective: To document the practice of labour in water, to assess the effects of water immersion during labor and/or birth (labour stages 1 , 2 and 3) on maternal, fetal and neonatal wellbeing and to compare the outcomes and safety with conventional vaginal deliveries and deliveries with epidural analgesia.

Material and Methods: Two-hundred and seven women electing for waterbirth $(n=207)$ were compared with women having conventional vaginal deliveries $(n=204)$ and vaginal deliveries with epidural analgesia $(n=191)$. Demographic data, length of $1^{\text {st }}, 2^{\text {nd }}$ and $3^{\text {rd }}$ stage of labor, induction and episiotomy requirements, perineal trauma, apgar scores, NICU requirements and VAS scores were noted.

Results: The $1^{\text {st }}$ stage of labor was shorter in waterbirths compared with vaginal delivery with epidural analgesia but the $2^{\text {nd }}$ and $3^{\text {rd }}$ stage of labor were shortest in patients having waterbirth compared with conventional vaginal delivery and vaginal delivery with epidural analgesia. Patients having waterbirth had less requirement for induction and episiotomy but had more perineal laceration. All women having waterbirths had reduced analgesia requirements and had lower scores on VAS. There was no difference in terms of NICU admission between the groups. Apgar scores were comparable in both groups. There were no neonatal deaths or neonatal infections during the study.

Conclusion: The study demonstrates the advantages of labor in water in terms of reduction in $2^{\text {nd }}$ and $3^{\text {rd }}$ stage of labor, reduction in pain and obstetric intervention such as induction or amniotomy. (J Turkish-German Gynecol Assoc 2012; 13: 45-9)

Key words: Water birth, analgesia, neonatal outcome

Received: 15 September, 2011

Accepted: 22 November, 2011

\section{Özet}

Amaç: Suda doğum pratiğinin dökümentasyonu ve doğum travayı ve/veya doğum eylemi (doğumun birinci, ikinci ve üçüncü evresi) sırasında maternal, fetal ve yenidoğan iyilik hali üzerine etkilerini değerlendirerek, sonuçları ve güvenirlilik açısından epidural analjezi ile vajinal doğum ve konvansiyonel vajinal doğum sonuçlanı ile kıyaslanması.

Gereç ve Yöntemler: Suda doğum yapan ikiyüzyedi $(n=207)$ kadın, konvansiyonel vajinal doğum yapan $(n=204)$ ve epidural analjezi ile vajinal doğum yapan $(n=191)$ kadınlarla kıyaslandı. Hastaların demografik verileri, doğum eyleminin 1., 2. ve 3. evresinin uzunluğu, indüksiyon ve epizyotomi ihtiyacı, perine travması, yenidoğanın apgar skorlaması, yoğun bakım ihtiyacı ve VAS skorları değerlendirildi.

Bulgular: Konvansiyonel vajinal doğum ve epidural analjezi ile vajinal doğum yapanlarla kıyaslandığında suda doğuranlarda, doğumun 1. evresi kısalmakla birlikte özellikle 2. ve 3. evrelerin çok kısalmıs olduğu görüldü. Suda doğum yapan hastalarda oksitosin ihtiyacı belirgin olarak daha azdı, epizyotomi oranı da daha düşüktü fakat daha fazla perineal laserasyon saptandı. Suda doğum yapan kadınların hepsinde analjezi ihtiyacı azalmıştı ve VAS skorları düşüktü. Gruplar arasında yenidoğan yoğun bakım ihtiyacı açısından fark yoktu. Apgar skorları benzerdi. Çalışma dönemi boyunca hiç yenidoğan ölümü veya yenidoğan enfeksiyonu saptanmadı.

Sonuçlar: Çalışma, suda doğumun, doğumun ikinci ve üçüncü evre sürelerini kısaltmak, doğum ağrısını azaltmak ve indüksiyon ve amniyotomi gibi obstetrik yaklaşım ihtiyacını azaltıcı avantajları olduğunu göstermiştir. (J Turkish-German Gynecol Assoc 2012; 13: 45-9)

Anahtar kelimeler: Suda doğum, analjezi, yenidoğan sonuçları

Geliş Tarihi: 15 Eylül 2011

Kabul Tarihi: 22 Kasım 2011

\section{Introduction}

In 1983, Odent published the results of the first hundred water births in The Lancet (1). It was postulated that anxiety and pain may trigger a stress response during labour (2) leading to reduced uterine activity and dystocia (3).
Labouring in water may overcome this stress response by aiding relaxation and relief of pain (4). Zanetti-Daellenbach et al. revealed that water deliveries performed in a selected low risk collective needed less analgesia had a shorter duration of first and second stages of labour, a lower episiotomy rate and were not associated with any adverse maternal

Address for Correspondence: Özlem Moraloğlu, Talatpaşa Bulvarı 158/5, Cebeci 06510 Ankara, Turkey

Phone: +905326855157 e.mail: ozlem.moraloglu@hotmail.com

(C) Copyright 2012 by the Turkish-German Gynecological Education and Research Foundation - Available online at www.jtgga.org doi:10.5152/jtgga.2012.03 
or fetal outcome (5). The advantages of immersion in water during labour and/or birth include reduced pain, increased functional diameter of the true pelvis, increased quality of contractions, increased release of endorphins, decreased need for opiates, increased movement for the mother as well as improved positioning in different stages of labour (6). There are also studies that have reported the disadvantages associated with water birth which include maternal and neonatal infections, as well as the possibility of respiratory problems for the newborn $(7,8)$. Cluett and Burns in a review of 11 trials concluded that water immersion during the first stage of labour reduced the use of epidural/spinal analgesia, but there was limited data for other outcomes related to water use during the first and second stages of labour (9). They also stated that there was no evidence of increased adverse effects on the fetus/neonate or woman from labouring in water (9).

The aim of this study is to document the practice of labour in water, to assess the effects of water immersion during labour and/or birth (labour stages 1, 2 and 3) on maternal, fetal and neonatal wellbeing and to compare the outcomes and safety with conventional vaginal deliveries and deliveries with epidural analgesia.

\section{Materials and Methods}

In a prospective clinical trial, the interview and observation techniques were used to study 610 pregnant women who were admitted to Zekai Tahir Burak Women's Health Education and Research Hospital, between June 2007 and September 2008. Women electing for water birth (Study Group 1, $n=207$ ) were compared with vaginal deliveries with epidural analgesia (Study Group 2, $\mathrm{n}=191$ ) and women having conventional vaginal deliveries (Control, $n=204$ ). The pregnant women were given comprehensive information on water birth before they were asked to participate in the study. Ethical approval was obtained from the local research ethics committee prior to the study, and written informed consent obtained from all patients. This study was conducted in accordance with the basic principles of the Helsinki Declaration. The inclusion criteria were gestational age between 37-42 weeks, no previous history of cesarean section, intact membranes, absence of placental abruption or placenta previa, no malpresentation, normal sized single fetus, and normal results of fetal wellbeing tests. The pregnant women with medical or obstetric risk factors were excluded $(n=8)$. Women presenting on the delivery suite with painful uterine contractions had an initial cervical assessment. This was taken as the onset of the active phase of labour in all groups. They were assigned to control and two study groups. The women were put in a standardized warm water pool which is large enough to allow the pregnant women move freely. At the time of delivery the water temperature was set to between 37 and $37.5^{\circ} \mathrm{C}$ so that the baby was not stimulated to breathe underwater by the cooler temperature of the pool. Fetal heart monitoring was performed at regular intervals with Doppler or NST. In the second stage of labour, care was taken to ensure the controlled delivery of the head of the fetus. The newborn was placed gently in the mother's arms within seconds but without rushing and then the cord clamped and cut. Delivery of the placenta and the membranes was completed outside the pool. After the delivery, the pool was emptied and cleaned with antiseptic solution. Cultures were taken for the determination of pathogenic bacteria. Demographic data, length of $1^{\text {st }}, 2^{\text {nd }}$ and $3^{\text {rd }}$ stages of labor, requirement for induction and episiotomy, perineal trauma, apgar scores, neonatal intensive care unit (NICU) requirements and visual analog scale (VAS) scores were noted on a questionnaire. The women evaluated their birth experience with the VAS (10 cm long VAS from 1 to 10 corresponding to the amount of pain felt by the woman with number 1 for no pain and with number 10 for dreadful pain).

\section{Statistical analysis}

Data were evaluated by SPSS for Windows release 15.0 (Chicago Inc.). To compare groups, we used the Chi-square test for categorical variables, Oneway ANOVA and Bonferroni tests for continuous variables that have normal distribution, Kruskall-Wallis oneway ANOVA for continuous variables that have no normal distribution. As described, variables, frequencies and percentages were given for categorical variables, Mean \pm standard deviations and median were given for continuous variables. Alpha $=0.05$ was accepted as a statistically significant value. In order to detect \pm 2 percentage point difference in VAS scores between groups, for having alpha $=0.05$, power $=0.97$, it was predicted that approximately 200 subjects for each group should be taken (NCSS-Pass Pocket Program was used) (Chow SC et al.) (10).

\section{Results}

The study groups consisted of 207 water births (Group 1) and 191 vaginal deliveries with epidural analgesia (Group 2), the control group (Group 3) of 204 patients gave birth by the conventional vaginal delivery method at the hospital. The women in the three groups were matched with respect to age, BMI and gestational age (Table 1). There were 276 primigravidae and 326 multiparous women having water births (Table 2). The mean age of the women were $26.2 \pm 5.1,26.1 \pm 4.5$ and $25.5 \pm 5.1$ respectively (Table 1 ). The mean cervical dilatation at admission in both group $1(5.3 \mathrm{~cm})$ and group $2(4.6 \mathrm{~cm})$ was not significantly different from group $3(4.7 \mathrm{~cm})$. The duration of the $1^{\text {st }}$ stage of labour was shortest in the conventional vaginal delivery group whereas the duration of the $2^{\text {nd }}$ and the $3^{\text {rd }}$ stages of labour were shortest in the water birth group (Table 1). There was a highly significant reduction in the induction and episiotomy requirements in the water birth group (Table 1). VAS scores were the lowest in the water birth group, so there was less analgesia requirement (Table 1). Conversely, the perineal laceration rate was higher in the water birth group, however most of these lacerations were minimal. Systolic and diastolic blood pressures seem to be lower in the water birth group, however the differences were not clinically significant. The decrease in hemoglobin levels as an indication of blood loss during labour were not statistically significant. The birthweight of the infants were highest, however Apgar scores were slightly lower in the water birth group. There was no difference in the 
Table 1. Demographic data, labour characteristics and neonatal outcomes of the three groups

\begin{tabular}{|c|c|c|c|c|}
\hline & Labour in water $(n=207)$ & $\begin{array}{c}\text { Vaginal delivery with } \\
\text { epidural analgesia }(n=191)\end{array}$ & $\begin{array}{c}\text { Conventional vaginal } \\
\text { delivery }(n=204)\end{array}$ & $\mathbf{p}$ \\
\hline Age (years) & $26.2 \pm 5.1$ & $26.1 \pm 4.5$ & $25.5 \pm 5.1$ & NS \\
\hline BMI $\left(\mathrm{kg} / \mathrm{m}^{2}\right)$ & $29.2 \pm 5.3$ & $28.2 \pm 6.3$ & $27.6 \pm 3.6$ & NS \\
\hline Gestational week (weeks) & $39.1 \pm 1.1$ & $39.1 \pm 1.3$ & $38.8 \pm 1.3$ & 0.0001 \\
\hline Antenatal care (n, \%) & $170(82.1 \%)$ & $179(33.7 \%)$ & $159(77.9 \%)$ & 0.0001 \\
\hline $1^{\text {st }}$ stage of labour (min) & $265.6 \pm 546.6$ & $268.7 \pm 177.4$ & $240.1 \pm 190.8$ & 0.0001 \\
\hline $2^{\text {nd }}$ stage of labour (min) & $10.9 \pm 5.02$ & $28.3 \pm 13.3$ & $23.9 \pm 14$ & 0.0001 \\
\hline $3^{\text {rd }}$ stage of labour (min) & $3.8 \pm 1.5$ & $5.3 \pm 4.4$ & $8.02 \pm 3.3$ & 0.0001 \\
\hline Induction $(\mathrm{n}, \%)$ & $11(5.3 \%)$ & $58(30.4 \%)$ & $57(27.9 \%)$ & 0.0001 \\
\hline Episiotomy $(\mathrm{n}, \%)$ & $56(27.1 \%)$ & $132(69.1 \%)$ & $182(89.2 \%)$ & 0.0001 \\
\hline Perineal laceration $(\mathrm{n}, \%)$ & $43(20.8 \%)$ & $13(6.8 \%)$ & $3(1.5 \%)$ & 0.0001 \\
\hline VAS* & $4.7 \pm 1.3$ & $5.8 \pm 0.9$ & $5.6 \pm 1.1$ & 0.0001 \\
\hline $\begin{array}{l}\text { Systolic blood pressure } \\
\text { (mmHg) }\end{array}$ & $110 \pm 11$ & $111 \pm 10$ & $113 \pm 9$ & 0.016 \\
\hline $\begin{array}{l}\text { Diastolic blood pressure } \\
\text { (mmHg) }\end{array}$ & $69 \pm 8$ & $70 \pm 9$ & $72 \pm 8$ & 0.013 \\
\hline Pulse (n) & $85 \pm 5$ & $85 \pm 6$ & $86 \pm 4$ & 0.063 \\
\hline $\begin{array}{l}\text { Decrease in hemoglobin } \\
\text { level }(g / d l)\end{array}$ & $0.22 \pm 1.1$ & $0.51 \pm 1.05$ & $-0.12 \pm 5.89$ & NS \\
\hline Birthweight $(\mathrm{g})$ & $3364.5 \pm 412.9$ & $3228.1 \pm 370.2$ & $3275.3 \pm 377.5$ & 0.002 \\
\hline \multicolumn{4}{|l|}{$1^{\text {st }}$ min Apgar scores } & 0.001 \\
\hline$<7$ & $26(12.6 \%)$ & $0(0.0 \%)$ & $3(1.5 \%)$ & \\
\hline$\geq 7$ & $181(87.4 \%)$ & $191(100 \%)$ & $201(98.5 \%)$ & \\
\hline \multicolumn{4}{|l|}{$5^{\text {th }}$ min Apgar scores } & $-\cdots$ \\
\hline$<7$ & $0(0.0 \%)$ & $0(0.0 \%)$ & $0(0.0 \%)$ & \\
\hline$\geq 7$ & $207(100 \%)$ & $191(100 \%)$ & $201(100 \%)$ & \\
\hline *NICU $(\mathrm{n}, \%)$ & $5(2.4 \%)$ & $7(3.7 \%)$ & $2(1 \%)$ & NS \\
\hline
\end{tabular}

rates of admissions to the NICU between the groups (Table 1). There were no documented neonatal infections. There was no adverse perinatal outcome or neonatal deaths. All the babies were born in good condition.

When primigravidas and multiparous women having water birth are considered (Table 2), the $1^{\text {st }}$ stage of labour is longer in both groups compared with controls, however the $2^{\text {nd }}$ and $3^{\text {rd }}$ stages of labour were the shortest in both primigravidas and multiparous women labouring in water compared with controls. The need for induction and episiotomy for both primigravidas and multiparous women was lowest in water birth group compared with others. Perineal laceration rates were higher in both groups compared with controls. VAS scores were lowest in the water birth group in both primigravidas and multiparous women. Apgar scores were slightly lower in the water birth group, however NICU admission rates were not statistically different in the water birth group for both primigravidas and multigravidas (Table 2).

\section{Discussion}

Water births have rapidly become one of the most popular birth methods. There is evidence of use of water immersion as a therapeutic medium for physical and psychological illnesses by the Chinese, Egyptians, Japanese and Assyrians, as well as Greeks and Romans (9). Water immersion during labour, including birth, used for relaxation and pain relief, has a long history. In 1995, the first international water birth conference was held in London, followed by many researches and conferences.

The positive physiological effects of hydrotherapy can facilitate the neurohormonal interactions of labour, reducing pain, and potentially facilitates the progress of labour $(11,12)$. Water immersion may be associated with improved uterine perfusion, less painful contractions and a shorter labour with fewer interventions (13-15). Several reports have shown that water immer- 
Table 2. Comparison of water birth, epidural analgesia and conventional vaginal delivery in primiparous and multiparous women

\begin{tabular}{|c|c|c|c|c|c|c|c|c|}
\hline & \multicolumn{4}{|c|}{ Primiparous $(n=276)$} & \multicolumn{4}{|c|}{ Multiparous $(n=326)$} \\
\hline & $\begin{array}{l}\text { Group } 1 \\
\text { (Labor in } \\
\text { water) }\end{array}$ & \begin{tabular}{|c|} 
Group 2 \\
(vaginal \\
delivery with \\
Epidural analgesia)
\end{tabular} & $\begin{array}{c}\text { Controls } \\
\text { (Conventional } \\
\text { vaginal delivery) }\end{array}$ & $\mathbf{p}$ & $\begin{array}{c}\text { Group 1 } \\
\text { (Labor } \\
\text { in water) } \\
\text { with Epidural } \\
\text { analgesia) }\end{array}$ & $\begin{array}{l}\text { Group 2 } \\
\text { (vaginal } \\
\text { delivery }\end{array}$ & $\begin{array}{c}\text { Controls } \\
\text { (Conventional } \\
\text { vaginal delivery) }\end{array}$ & $\mathbf{p}$ \\
\hline & $(n=52)$ & $(n=156)$ & $(n=68)$ & & $(n=155)$ & $(n=35)$ & $(n=136)$ & \\
\hline $1^{\text {st }}$ stage $(\min )$ & $331.3 \pm 832.5$ & $282.7 \pm 184.0$ & $300 \pm 151.9$ & 0.002 & $245.3 \pm 423.7$ & $204.6 \pm 126.1$ & $210.0 \pm 201.3$ & 0.012 \\
\hline $\begin{array}{l}2^{\text {nd }} \text { stage } \\
\text { (min) }\end{array}$ & $11 \pm 5$ & $28.6 \pm 13.7$ & $27.2 \pm 16.7$ & 0.0001 & $10.9 \pm 5.01$ & $26.8 \pm 11.6$ & $22.2 \pm 12.1$ & 0.0001 \\
\hline $\begin{array}{l}3^{\text {rd }} \text { stage } \\
(\mathrm{min})\end{array}$ & $3.9 \pm 2.3$ & $5.5 \pm 4.6$ & $7.6 \pm 3.2$ & 0.0001 & $3.7 \pm 1.2$ & $4.5 \pm 3.3$ & $8.1 \pm 3.3$ & 0.0001 \\
\hline $\begin{array}{l}\text { Induction } \\
(\mathrm{n}, \%)\end{array}$ & $3(5.8 \%)$ & $50(32.1 \%)$ & $30(44.1 \%)$ & 0.0001 & $8(5.2 \%)$ & $8(22.9 \%)$ & $27(19.9 \%)$ & 0.0001 \\
\hline $\begin{array}{l}\text { Episiotomy } \\
(\mathrm{n}, \%)\end{array}$ & 27 (51.9\%) & $105(67.3 \%)$ & $66(97.1 \%)$ & 0.0001 & $29(18.7 \%)$ & $27(77.1 \%)$ & $116(85.3 \%)$ & 0.0001 \\
\hline $\begin{array}{l}\text { Perineal } \\
\text { laseration (n, \%) }\end{array}$ & $14(26.9 \%)$ & $10(6.4 \%)$ & $1(1.5 \%)$ & 0.0001 & $29(18.7 \%)$ & $3(8.6 \%)$ & $2(1.5 \%)$ & 0.0001 \\
\hline VAS* & $4.6 \pm 1.2$ & $5.8 \pm 1.04$ & $5.7 \pm 0.97$ & 0.0001 & $4.7 \pm 1.3$ & $5.8 \pm 0.7$ & $5.6 \pm 1.18$ & 0.0001 \\
\hline $\begin{array}{l}\text { Apgar } 1^{\text {st }} \min \\
>=7\end{array}$ & $40(76.9 \%)$ & $156(100 \%)$ & $67(98.5 \%)$ & 0,001 & $141(91.0 \%)$ & $35(100 \%)$ & $134(98.5 \%)$ & 0.004 \\
\hline$<7$ & $12(23.1 \%)$ & $0(0.0 \%)$ & $1(1.5 \%)$ & & $14(9.0 \%)$ & $0(0.0 \%)$ & $2(1.5 \%)$ & \\
\hline $\begin{array}{l}\text { Apgar } 5^{\text {th }} \\
\min >=7\end{array}$ & $52(100)$ & $156(100 \%)$ & $68(100 \%)$ & --- & $155(100)$ & $35(100 \%)$ & $136(100 \%)$ & --- \\
\hline NICU* & $4(7.7 \%)$ & $7(4.5 \%)$ & 0 & NS & $1(0.6 \%)$ & 0 & $2(1.5 \%)$ & NS \\
\hline
\end{tabular}

sion shortens the process of labour $(1,15)$, however some others found no significant difference for the duration of the 1st stages of labour $(13,16-20)$. The present study also demonstrates that the 1st stage of labour is not shortened by immersion in water in either primigravidas or multigravidas. Cammu et al., Eckert et al., Rush et al. and Woodward et al. provided data on analgesia and anesthesia use in their studies and found that there was a significant reduction in the incidence of analgesia and anesthesia use among women placed in water during the first stage of labour $(16,17,19,20)$. In the present study, we have shown that VAS scores indicating the pain felt by the women were lowest among women having water birth, even lower than the women labouring with epidural analgesia. In agreement with these studies, we observed that immersion in water greatly reduces the pain and need for additional analgesia.

Labouring in water has been found to reduce stress hormones and cathecolamines which inhibit oxytocin and labour progress (9). In our study, the duration of the second stage of labour was found to be shorter in water births, consistent with the results of studies of Chaichian et al. and Otigbah et al. (6, $21)$. The fetus may be more likely to adopt a more relaxed and flexed position, because the mother can easily explore different positions to maximise her pelvic diameters (22). The duration of the $3^{\text {rd }}$ stage of labour, which is the delivery of the placenta, is also significantly reduced after water births. This minimizes amount of blood loss during this period. The lower blood loss in water births can also be explained by the hydrostatic pressure in the pool, by the less severe lacerations or possibly by a facilitated control of the third stage of labour.

In the study, patients having waterbirth had less requirement for obstetric interventions such as induction and episiotomy but had more perineal lacerations. However, the lacerations in water birth group were less severe than those in epidural analgesia and conventional delivery group. Otigbah et al. found that primigravidas having water births had less perineal trauma and the overall episiotomy rate was 5 times greater in the control group, but overall, more women having water births had perineal tears (21). On the other hand, there are studies which show no difference in perineal trauma $(23,24)$. The reason why women having water births had more tears may be explained by the difficulty in accessing the women's perineum during birth, resulting in more perineal trauma. However, the widespread belief that with episiotomies $3^{\text {rd }}$ and $4^{\text {th }}$ degree lacerations are avoided is open to question, because in our study episiotomy rates were lowest after water births, and the lacerations were minimal. 
There are some concerns about water birth for the fetus. These are thermoregulation during labour, infection and onset of respiration at birth. As the water temperature of the pool does not exceed the maternal body temperature, fetal hyperthermia and associated cardiovascular and metabolic disturbances will not occur (25). None of the newborns in our study took its first breath in water. This has been explained by the diving reflex which shows that, when the face or especially the glottis comes in contact with fluid, respiration movements are inhibited. Aspiration will occur only when the diving reflex fails, because of anesthesia or severe asphyxia or because of the inappropriate pool temperature. When we consider neonatal infection, several reported comparative studies, cohort studies and audits report no increased risk of infection to the newborn $(5,19,21)$. This is also confirmed by the study that there were no documented neonatal infections. Overall, water birth does not cause an increased risk of adverse effects to the fetus/newborn.

In conclusion, the study demonstrates the advantages of water birth in terms of reduction in the duration of the $2^{\text {nd }}$ and $3^{\text {rd }}$ stages of labor, reduction in pain and obstetric intervention such as induction or episiotomy. Labouring in water significantly reduces pain and the requirement of epidural/spinal analgesia. It is a management approach which contributes positively to maternal physiological and psychological health by reducing the augmentation which is known to increase the risk of uterine hyperstimulation and fetal hypoxia and by reducing the obstetric interventions which are associated with lower maternal satisfaction. There is no increased adverse effects to the fetus or labouring women. Water birth may be an alternative birth method that can be offered in selected patients.

\section{Conflict of interest}

No conflict of interest was declared by the authors.

\section{References}

1. Odent M. Birth under water. Lancet 1983; 2: 1476-7. [CrossRef]

2. Brownridge $P$. The nature and consequences of childbirth pain. Eur J Obstet Gynecol Reprod Biol. 1995; 59: 9-15. [CrossRef]

3. De Punzio C, Neri E, Metelli P, Bianchi MS, Venticinque M, Ferdeghini $\mathrm{M}$, et al. The relationship between maternal relaxation and plasma beta-endorphin levels during parturition. J Psychosom Obstet Gynaecol 1994; 15: 205-10. [CrossRef]

4. Elizabeth R Cluett, Ruth M Pickering, Kathryn Getliffe, Nigel James St George Saunders. Randomised controlled trial of labouring in water compared with standard of augmentation for management of dystocia in first stage of labour. BMJ 2004; 328: 314-8.

5. Zanetti-Daellenbach RA, Tschudin S, Zhong XZ, Holzgreve W, Lapaire O, Hösli I. Maternal and neonatal infection and obstetri- cal outcome in water birth. European Journal of Obstetrics \& Gynecology and Reproductive Biology 2007; 134: 37-43. [CrossRef]

6. Chaichian S, Akhlaghi A, Rousta F, Safavi M. Experience of water birth delivery in Iran. Arch Iran Med 2009; 12: 468-71.

7. Rawal J, Shah A, Stirk F, Mehtar S. Water birth and infection in babies. BMJ. 1994; 20: 309: 511.

8. Geissbühler V, Eberhard J. Experience with water births: a prospective longitudinal study of 9 years with almost 4,000 water births. Gynakol Geburtshilfliche Rundsch 2003; 43: 12-8.

9. Cluett ER, Burns E. Immersion in water in labour and birth. Cochrane Database of Systematic Reviews 2009; 2: CD000111.

10. Chow SC, Shao J, Wang H. Sample Size Calculation in Clinical Research. Second Edition. Chapman \& Hall, New York 2008. pp: 70-4.

11. Ginesi L, Niescierowicz R. Neuroendocrinology and birth 1: stress. British Journal of Midwifery 1998; 6: 659-63.

12. Ginesi L, Niescierowicz R. Neuroendocrinology and birth 2: The role of oxytocin. British Journal of Midwifery 1998; 6: 791-6.

13. Schorn MN, McAllister JL, Blanco JD. Water immersion and the effect on labor. J Nurse Midwifery 1993; 38: 336-42. [CrossRef]

14. Geissbuehler V, Eberhard J. Waterbirths a comparative study. Aprospective study on more than 2,000 waterbirths. Fetal Diagnosis and Therapy 2000; 15: 291-300.

15. Burke E, Kilfoyle A. A comparative study, waterbirth and bed birth. Midwives 1995; 108: 3-7.

16. Cammu H, Clasen K, Wettere L, Derde M-P. To bathe or not to bathe during the first stage of labor. Acta Obstet Gynecol Scand 1994; 73: 468-72. [CrossRef]

17. Eckert $K$, Turnbull $D$, MacLennan A. Immersion in water in the first stage of labour: a randomised controlled trial. Birth 2001; 28: 84-93. [CrossRef]

18. Kuusela P, Koivisto A-M, Heinonen PK. Warn tub bath during opening phase of labor [Lammin kylpy synnytyksen avautumisvaiheessa]. Suomen Laakarilehti 1998; 11: 1217-21.

19. Rush J, Burlock S, Lambert K, Loasley-Milman M, Hutchinson B, Enkin M. The effects of whirlpool baths in labour: a randomised controlled trial. Birth 1996; 23: 136-43. [CrossRef]

20. Woodward J, Kelly SM. A pilot study for a randomised controlled trial of waterbirth versus land birth. BJOG 2004; 111: 537-45. [CrossRef]

21. Otigbah CM, Dhanjal MK, Harmsworth G, Chard T. A retrospective comparison of water births and conventional vaginal deliveries. Eur J Obstet Gynecol Reprod Biol 2000; 91: 15-20. [CrossRef]

22. Ohlsson G, Buchhave P, Leandersson U, Nordstrom L, Rydhstrom $\mathrm{H}$, Sjolin I. Warm tub bathing during labor; maternal and neonatal effects. Acta Obstet Gynecol Scand 2001; 80: 311-4. [CrossRef]

23. Lenstrup C, Schantz A, Berget A, Feder E, Rosenø H, Hertel J. Warm tub bath during delivery. Acta Obstet Gynecol Scand 1987; 66: 709-12. [CrossRef]

24. Church LK. Water birth: one birthing center's observations. Journal of Nurse-Midwifery 1989; 34: 165-70. [CrossRef]

25. Johnson P. Birth under water - to breathe or not to breathe. BJOG 1996; 103: 202-8. [CrossRef] 